\title{
ANALISIS DISIPLIN DAN LINGKUNGAN KERJA SERTA PENGARUHNYA TERHADAP KINERJA PEGAWAI PADA ASISTEN DEPUTI SDM PARIWISATA DAN HUBUNGAN ANTAR LEMBAGA KEMENTERIAN PARIWISATA RI
}

\author{
Oleh: \\ Esti Handayani1), Meryati'2), Siti Laela ${ }^{3)}$ \\ esti.aulia@yahoo.co.id ${ }^{11}$, merry.santoso@catlover.com ${ }^{2}$, siti_laela65@yahoo.com ${ }^{3}$ ) \\ Sekolah Tinggi Ilmu Ekonomi IPWI Jakarta1,2,3)
}

\begin{abstract}
ABSTRAK
Bagi organisasi tak terkecuali lembaga pemerintahan yang sudah mencapai kinerja lembaga yang baik tetap menghadapi permasalahan dalam kelembagaan, yaitu bagaimana mempertahankan kinerja pegawai agar tetap tinggi. Untuk itu penelitian ini bertujuan untuk menganalisis bagaimana pengaruh disiplin kerja dan lingkungan kerja terhadap kinerja pegawai pada salah satu deputi yaitu Asisten Deputi SDM Pariwisata dan Hubungan Antar Lembaga Kementerian Pariwisata RI.

Penelitian ini dilakukan selain dengan interview dalam pengumpulan data juga dilakukan dengan menyebar kuesioner kepada pegawai pada Asisten Deputi SDM Pariwisata dan Hubungan Antar Lembaga Kementerian Pariwisata RI. Kuesioner diisi oleh 67 responden sebagai sampel yang diambil dari total populasi 200 pegawai. Pengambilan jumlah sampel berdasarkan perhitungan menggunakan rumus Slovin. Skala pengukuran dalam penelitian ini adalah menggunakan skala lima, yaitu dimulai dari skala satu sangat tidak setuju sampai sangat setuju dengan skala lima.

Model analisis penelitian ini menggunakan analisis regresi berganda, untuk itu dilakukan juga uji instrumen, uji asumsi klasik dan uji hipotesis. Dalam pengolahan data penelitian menggunakan software SPSS.

Hasil analisis dan pengolahan data dalam penelitian ini diperoleh temuan bahwa disiplin dan lingkungan kerja berpengaruh signifikan terhadap kinerja pegawai sebesar 65,2\% pada Asisten Deputi SDM Pariwisata dan Hubungan Antar Lembaga Kementerian Pariwisata RI. Pengaruh Disiplin terhadap kinerja diperoleh hasil sebesar 0,290 yang berarti disiplin memiliki pengaruh yang lebih kecil daripada pengaruh lingkungan kerja terhadap kinerja yaitu sebesar 0,527.
\end{abstract}

Kata Kunci: disiplin, lingkungan kerja, kinerja pegawai

\section{PENDAHULUAN}

Suatu organisasi didirikan karena mempunyai tujuan yang ingin dicapai. Sumber daya manusia merupakan tokoh sentral dalam organisasi guna tercapainya tujuan organisasi secara maksimal. Sumber daya yang berpengetahuan dan berketerampilan tinggi sangat diperlukan bagi kelancaran aktivitas organisasi. Disamping itu diperlukan juga untuk mengelola organisasi secara optimal sehingga kinerja pekerja meningkat. Karena itu perusahaan harus memiliki pegawai 
yang memiliki kedisiplinan tinggi, memiliki pengetahuan, keterampilan, karya dan potensi-potensi lain yang perlu dimiliki. Menurut Hasibuan (2012: 10) menyatakan "sumber daya manusia adalah ilmu dan seni mengatur hubungan dan peranan tenaga kerja agar efektif dan efisien, membantu terwujudnya tujuan perusahaan, pegawai dan masyarakat".

Semakin berkembangnya teknologi, pendidikan dan pertumbuhan ekonomi yang semakin meningkat para pelaku yang bergerak dibidang ekonomi, budaya maupun bidang lain dapat mempengaruhi tujuan organisasi yang akan dicapai dimasa mendatang. Salah satu usaha yang perlu dilakukan perusahaan dalam menghadapi tantangan dari lingkungan luar maka diperlukan pengawasan terhadap kinerja pegawai dan penyediaan fasilitas penunjang guna meningkatkan prestasi kerja sumber daya manusia. Prestasi kerja pegawai merupakan dasar peningkatan (promosi jabatan), kenaikan kompensasi, mutasi dan pemberhentian kerja. Guna mengetahui prestasi kerja pegawai dilakukan penilaian prestasi kerja melalui proses penilaian kinerja.

Beberapa faktor yang mempengaruhi prestasi kerja diantaranya adalah disiplin kerja dan lingkungan kerja. Disiplin kerja merupakan hal yang berpengaruh pada tingkat prestasi kerja seorang individu dalam suatu perusahaan (Rivai, 2009: 825) Disiplin merupakan hal yang penting dalam suatu organisasi karena keberhasilan suatu organisasi dapat diukur seberapa besar kedisiplinan pegawainya. Disiplin kerja merupakan sikap mental dalam diri seorang pegawai yang menjadi salah satu faktor yang mempengaruhi kinerja (Sedarmayanti, 2001). Beberapa indikator disiplin diantaranya kehadiran, ketaatan pada peraturan kerja, ketaatan pada standar kerja (Rivai, 2005). Pegawai harus patuh dan tunduk kepada norma-norma yang berlaku pada organisasi. Semakin baik kedisiplinan pegawai maka semakin tinggi prestasi yang dapat diraih organisasi. Nilai-nilai kepatuhan telah menjadi bagian perilaku pegawai bagi organisasi. Disiplin akan membuat diri seseorang dapat membedakan hal-hal yang wajib dilakukan dan tidak harus dilakukan.

Kementerian Pariwisata RI khususnya pada Asisten Deputi SDM Pariwisata dan Hubungan Antar Lembaga juga perlu memahami lingkungan kerja pegawai baik yang terkait secara langsung maupun tidak langsung dengan kegiatan organisasi. Lingkungan kerja dapat mempengaruhi seseorang dalam melaksanakan aktivitas kerja secara efektif dan efisien. Ishak dan Tanjung (2003: 26) menyatakan "fungsi dari lingkungan kerja dalam organisasi adalah menciptakan gairah kerja, sehingga produktivitas dan prestasi kerja menigkat".

Lingkungan kerja yang nyaman dapat mempengaruhi kinerja pegawai agar dalam pelaksanaan tugasnya dapat dikerjakan secara optimal. Lingkungan kerja yang nyaman, aman dan tenang merupakan salah satu faktor utama meningkatkan kinerja pegawai dalam mencapai tujuan. Lingkungan kerja yang kurang menarik dan kurang memuaskan dapat menurunkan produktivitas kerja pegawai, begitu juga sebaliknya bila lingkungan kerja yang kondusif maka peningkatan kinerja pegawai pada Kementerian Pariwisata RI dapat terwujud dan tujuan organisasi yang telah direncanakan akan tercapai.

Saat ini mempertahankan tenaga kerja yang berkinerja baik sangatlah tidak mudah, oleh karena itu perusahaan harus memprioritaskan pegawai yang berkeahlian dan memiliki kinerja baik agar dapat dikembangkan sesuai yang dikehendaki perusahaan. Salah satu alat ukur untuk menentukan efektifitas perusahaan adalah hasil kinerja pegawai. Mathis (2002: 78) berpendapat bahwa "kinerja pegawai adalah apa yang dilakukan atau tidak oleh pegawai mempengaruhi seberapa banyak mereka memberi kontribusi kepada organisasi".

\section{TUJUAN PENELITIAN}

Tujuan penelitian ini adalah untuk mengetahui pengaruh Disiplin dan 
Lingkungan Kerja terhadap Kinerja Pegawai pada Asisten Deputi SDM Pariwisata dan Hubungan Antar Lembaga Kementerian Pariwisata RI.

\section{TELAAH LITERATUR DAN PENGEMBANGAN PROPOSISI/HIPOTESIS Disiplin Kerja}

Setiap perusahaan/organisasi yang menginginkan kemajuan harus dapat mewujudkan disiplin kerja pegawainya. Dengan disiplin kerja yang baik berarti produktivitas akan meningkat. Menurut Malayu S.P. Hasibuan (2005:193), menyatakan bahwa kedisiplinan adalah kesadaran dan kesediaan seseorang mentaati semua peraturan perusahaan dan norma-norma sosial yang berlaku.

Soejitno Irmim (2004:21) menyatakan bahwa "kedisiplinan adalah (1) perilaku yang menunjukkan nilainilai ketaatan, kepatuhan, kesetiaan, keteraturan dan ketertiban, (2) perasaan risi atau merasa malu dan berdosa bila melakukan kegiatan atau perilaku yang menyimpang, (3) sikap tahu untuk membedakan hal-hal yang perlu dilakukan, yang wajib dilakukan, yang boleh dilakukan dan yang pantas dilakukan, (4) merupakan sikap taat, tertib sebagai hasil dari pengembangan latihan, pengendalian pikiran dan pengendalian watak, (5) pemahaman dan pelaksanaan yang baik mengenai sistem aturan perilaku, norma, kriteria, dan standar sehingga dapat mengontrol perilaku sehari-hari".

Siagian (2012:305), mengemukakan bahwa "disiplin karyawan dalam manajemen sumber daya manusia berangkat dari pandangan bahwa tidak ada manusia yang sempurna, lepas dari kesalahan dan kekhilafan". Jadi disiplin karyawan adalah suatu bentuk pelatihan karyawan yang berusaha memperbaiki dan membentuk pengetahuan, sikap dan perilaku karyawan sehingga perilaku karyawan tersebut secara sukarela berusaha bekerja secara koperatif dengan para karyawan lain serta meningkatkan prestasi kerja.
Disiplin kerja adalah suatu alat yang digunakan para manajer untuk berkomunikasi dengan karyawan agar mereka bersedia untuk mengubah suatu perilaku serta sebagai suatu upaya untuk meningkatkan kesadaran dan kesediaan seseorang mentaati semua peraturan perusahaan dan normanorma yang berlaku (Rivai 2010: 825).

Tanpa mengurangi makna disiplin kerja dapat disimpulkan sebagai suatu sikap taat pada aturan dan norma yang berlaku pada perusahaan/organisasi serta siap menerima sanksi atas kesalahan yang telah dilakukan dengan penuh kesadaran.

Menurut Rivai (2010), menjelaskan bahwa disiplin kerja memiliki beberapa indikator, diantaranya adalah sebagai berikut:

1) Kehadiran

Kehadiran menjadi indikator yang mendasar untuk mengukur kedisiplinan karyawan, biasanya karyawan yang memiliki disiplin kerja rendah terbiasa untuk datang terlambat dalam bekerja.

2) Ketaatan pada peraturan kerja Karyawan yang taat pada peraturan kerja selalu mengikuti pedoman kerja dan tidak akan melalaikan prosedur kerja yang ditetapkan oleh organisasi atau perusahaan.

3) Ketaatan pada standar kerja

Hal ini dapat dilihat melalui besarnya tanggung jawab karyawan terhadap tugas yang diamanahkan kepadanya.

4) Tingkat kewaspadaan tinggi

Karyawan memiliki kewaspadaan tinggi akan selalu berhati-hati, penuh perhitungan dan ketelitian dalam bekerja, serta selalu menggunakan sesuatu secara efektif dan efisien.

5) Bekerja etis

Beberapa karyawan mungkin melakukan tindakan yang tidak sopan ke pelanggan atau terlibat dalam tindakan yang tidak pantas. Hal ini merupakan salah satu bentuk tindakan indisipliner, sehingga bekerja etis sebagai salah satu wujud dari disiplin kerja karyawan. 


\section{Lingkungan Kerja}

Lingkungan kerja merupakan segala sesuatu yang ada disekitar pekerja dan dapat mempengaruhi dalam bekerja meliputi pengaturan penerangan, pengontrolan suara gaduh, pengaturan kebersihan tempat kerja dan pengaturan keamanan tempat kerja. Perusahaan harus dapat memperhatikan kondisi yang ada dalam perusahaan baik didalam maupun diluar ruangan tempat kerja, sehingga karyawan dapat bekerja dengan lancar dan merasa aman.

Perusahaan/organisasi hendaknya dapat mencerminkan kondisi yang mendukung kerja sama antara tingkat atasan, bawahan maupun yang memiliki status jabatan yang sama di perusahaan/organisasi. Kondisi yang hendaknya diciptakan adalah suasana kekeluargaan, komunikasi yang baik dan pengendalian diri. Lingkungan kerja dapat diartikan sebagai kekuatankekuatan yang memengaruhi, baik secara langsung maupun tidak langsung terhadap kinerja organisasi atau perusahaan (Terry, 2006).

Schultz \& Schultz (2006), mengartikan "lingkungan kerja sebagai suatu kondisi yang berkaitan dengan ciri-ciri tempat bekerja terhadap perilaku dan sikap karyawan dimana hal tersebut berhubungan dengan terjadinya perubahan-perubahan psikologis karena hal-hal yang dialami dalam pekerjaannya atau dalam keadaan tertentu yang harus terus diperhatikan oleh organisasi yang mencakup kebosanan kerja, pekerjaan yang monoton dan kelelahan". Menurut Sedarmayanti (2017:21), "lingkungan kerja adalah keseluruhan alat perkakas dan bahan yang dihadapi, lingkungan sekitarnya di mana seseorang bekerja, metode kerjanya, serta pengaturan kerjanya baik sebagai perseorangan maupun sebagai kelompok". Lingkungan kerja adalah sesuatu yang ada di sekitar para pekerja dan yang memengaruhi dirinya dalam menjalankan tugas-tugas yang dibebankan (Alex Nitisemito, 2010).

Dari beberapa pendapat di atas, disimpulkan bahwa lingkungan kerja merupakan segala sesuatu yang ada di sekitar karyawan pada saat bekerja, baik yang berbentuk fisik ataupun non fisik, langsung atau tidak langsung yang dapat mempengaruhi dirinya dan pekerjaanya saat bekerja.

Indikator lingkungan kerja yang dikemukakan oleh Alex Nitisemito (2010), yaitu sebagai berikut:

1) Suasana kerja

Suasana kerja adalah kondisi yang ada di sekitar karyawan yang sedang melakukan pekerjaan yang dapat memengaruhi pelaksanaan pekerjaan itu sendiri.

2) Hubungan dengan rekan kerja Hubungan dengan rekan kerja yaitu hubungan dengan rekan kerja yang harmonis dan tanpa ada saling intrik diantara sesama rekan sekerja.

3) Hubungan antara bawahan dengan pimpinan

Hubungan yang baik dan harmonis dengan pimpinan tempat kerja merupakan faktor penting yang dapat memengaruhi kinerja karyawan.

4) Tersedianya fasilitas kerja

Tersedianya fasilitas kerja yang lengkap, walaupun tidak baru merupakan salah satu penunjang proses dalam bekerja.

\section{Kinerja Pegawai}

Kinerja pegawai dalam organisasi mengarah kepada kemampuan pegawai dalam melaksanakan keseluruhan tugas-tugas yang menjadi tanggung jawabnya. Tugas-tugas tersebut biasanya berdasarkan indikatorindikator keberhasilan yang sudah ditetapkan. Sebagai hasilnya akan diketahui bahwa seorang pegawai masuk dalam tingkatan kinerja tertentu. Kinerja merupakan kombinasi antara kemampuan dan usaha untuk menghasilkan apa yang dikerjakan. Menurut Mahsun (2006), bahwa "kinerja merupakan gambaran mengenai tingkat pencapaian pelaksanaan suatu kegiatan, program, kebijakan dalam mewujudkan sasaran, tujuan, misi dan visi yang tertuang dalam perencanaan strategi organisasi". Sedangkan Simanjuntak (2005), menyatakan bahwa "kinerja adalah tingkatan pencapaian hasil atas pelaksanaan tugas tertentu dalam 
rangka mewujudkan pencapaian hasil untuk mencapai tujuan perusahaan". Menurut Mangkunegara (2011), "kinerja karyawan (prestasi kerja) adalah hasil kerja secara kualitas dan kuantitas yang dicapai oleh seseorang karyawan dalam melaksanakan tugasnya sesuai dengan tanggung jawab yang diberikan kepadanya". Menurut Ilyas (2012), "Kinerja adalah penampilan hasil karya karyawan baik kuantitas maupun kualitas dalam suatu organisasi/perusahaan".

Menurut Ilyas (2012), indikator kinerja karyawan meliputi:

1. Prestasi Kerja

Prestasi kerja merupakan hasil pelaksanaan pekerjaan yang dicapai oleh seorang karyawan dalam melaksanakan tugas yang dibebankan kepadanya.

2. Tanggung Jawab

Kesanggupan seorang karyawan dalam menyelesaikan pekerjaan yang diserahkan kepadanya dengan sebaik-baiknya, tepat waktu serta berani memikul resiko atas keputusan yang diambilnya atau tindakan yang dilakukan.

3. Ketaatan

Kesanggupan seorang karyawan untuk mentaati segala peraturan kedinasan yang berlaku dan mentaati perintah kedinasan yang diberikan oleh atasan yang berwenang, serta sanggup untuk tidak melanggar larangan yang ditentukan.

4. Kejujuran

Kejujuran merupakan sikap mental yang keluar dari dalam diri manusia dan merupakan ketulusan hati dalam melaksanakan tugas dan mampu untuk tidak menyalahgunakan wewenang dan tanggung jawab yang diberikan kepadanya.

5. Kerjasama

Kerjasama merupakan kemampuan mental seorang karyawan untuk dapat bekerja bersama-sama dengan orang lain dalam menyelesaikan tugas-tugas yang telah ditentukan.

6. Inisiatif
Inisiatif merupakan kemampuan seorang karyawan untuk mengambil keputusan, langkah-langkah, serta melaksanakannya, sesuai dengan tindakan yang diperlukan dalam pelaksanaan tugas pokok tanpa menunggu perintah atasan.

\section{Disiplin Kerja dan Kinerja Pegawai}

Penelitian yang dilakukan oleh Rizon Pranata (2014), menemukan bahwa motivasi dan disiplin baik secara parsial maupun simultan berpengaruh positif dan signifikan terhadap kinerja karyawan. Muhammad Taufiek Rio Sanjaya (2015) mengemukakan hasil penelitiannya bahwa disiplin dan motivasi berpengaruh positif dan signifikan terhadap kinerja karyawan. Hasil analisis data yang dilakukan oleh Tri Widari (2016), menyimpulkan disiplin dan lingkungan kerja berpengaruh positif dan signifikan terhadap kinerja karyawan. Berdasarkan penelitian-penelitian tersebut, maka hipotesis pertama diajukan sebagai berikut:

H1: Terdapat pengaruh yang signifikan antara disiplin terhadap kinerja pegawai

\section{Lingkungan Kerja dan Kinerja Pegawai}

Dilian Diah Pertiwi (2014) dengan hasil penelitiannya yaitu kompensasi, motivasi dan lingkungan kerja berpengaruh positif dan signifikan terhadap kinerja karyawan. Penelitian lain dikemukakan oleh Aditya Nur Pratama (2016) yang menyatakan berdasarkan dari analisa datanya bahwa lingkungan kerja dan disiplin berpengaruh positif dan signifikan terhadap kinerja karyawan. Berdasarkan penelitian-penelitian tersebut, maka hipotesis kedua diajukan sebagai berikut:

H2: Terdapat pengaruh yang signifikan antara lingkungan kerja terhadap kinerja pegawai

\section{Kerangka Pemikiran}

Berdasarkan penelitian-penelitian terdahulu, maka paradigma penelitian tentang hubungan disiplin dan lingkungan kerja terhadap kinerja 
pegawai dapat digambarkan sebagai berikut:

Gambar 1

Kerangka/Konstelasi

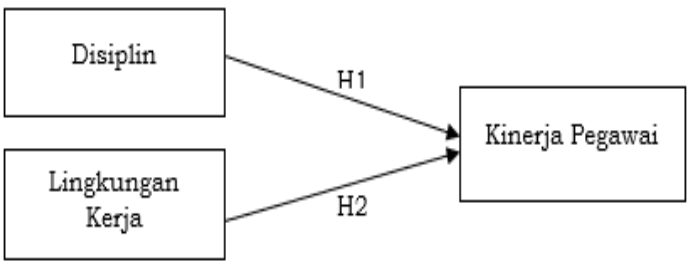

\section{METODE PENELITIAN \\ Populasi dan sampel}

Populasi dalam penelitian ini adalah 200 orang pegawai pada Asisten Deputi SDM Pariwisata dan Hubungan Antar Lembaga Kementerian Pariwisata RI yang beralamat di Gedung Film Jl. MT. Haryono Kav. 47-48 Jakarta Selatan. Penelitian dilakukan pada bulan Juni s.d. September 2019.

Teknik pengambilan sampel dengan probability sampling dengan menggunakan teknik sampel acak sederhana (simple random sampling). Jumlah sampel ditentukan menggunakan rumus Slovin dengan tingkat kesalahan yang ditoleransikan sebesar $10 \%$ dengan signifikansi sebesar 90\%. Berdasarkan perhitungan, diperoleh ukuran sampel representative yang diperlukan peneliti adalah sebanyak 67 orang.

\section{Desain Penelitian}

Jenis penelitian yang digunakan dalam penelitian ini adalah explanatory research yang menjelaskan hubungan kausal antara variabel-variabel penelitian melalui pengujian hipotesa (Singarimbun dan Efendi, 2009) dengan menggunakan pendekatan kuantitatif. Penelitian ini menjelaskan pengaruh antara variabel independen yaitu disiplin (X1) dan lingkungan kerja (X2) terhadap variabel dependen yaitu kinerja karyawan (Y). Kerangka pengaruh variabel independen terhadap variabel dependen pada penelitian ini adalah sebagai berikut:
Gambar 2

Desain Penelitian Sig $F(\alpha=0,05)$

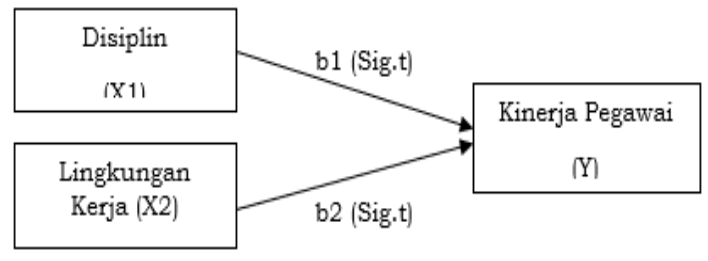

\section{Operasionalisasi Variabel}

Operasionalisasi variabel pada penelitian ini adalah sebagai berikut:

\begin{tabular}{|c|c|c|c|}
\hline Variabe1 & Definisi & Indikator & $\begin{array}{c}\text { Skala } \\
\text { Pengukuran }\end{array}$ \\
\hline $\begin{array}{l}\text { DISIPLIN (X1) } \\
\text { Rivai (2010) }\end{array}$ & $\begin{array}{l}\text { Disiplin adalah suatu } \\
\text { alat yang digunakan } \\
\text { para manajer untuk } \\
\text { berkomunikasi dengan } \\
\text { karyawan agar mereka } \\
\text { bersedia untuk } \\
\text { mengubah } \\
\text { suatu perilaku serta } \\
\text { sebagai suatu upaya } \\
\text { untuk meningkatkan } \\
\text { kesadaran dan } \\
\text { kesediaan seseorang } \\
\text { mentaati semua } \\
\text { peraturan perusahaan } \\
\text { dan norma-norma yang } \\
\text { berlaku. }\end{array}$ & $\begin{array}{l}\text { a. Kehadiran } \\
\text { b. Ketaatan pada } \\
\text { peraturan } \\
\text { kerja } \\
\text { c. Ketaatan pada } \\
\text { standar kerja } \\
\text { d. Tingkat } \\
\text { kewaspadaan } \\
\text { tinggi } \\
\text { e. Bekerja etis }\end{array}$ & $\begin{array}{l}\text { Skala } \\
\text { Likert } \\
(1-5)\end{array}$ \\
\hline $\begin{array}{l}\text { LINGKUNGAN } \\
\text { KERJA (X2) } \\
\text { Alex Nitisemito } \\
(2010)\end{array}$ & $\begin{array}{l}\text { Lingkungan kerja } \\
\text { adalah sesuatu yang } \\
\text { ada di sekitar para } \\
\text { pekerja dan yang } \\
\text { memengaruhi dirinya } \\
\text { dalam menjalankan } \\
\text { tugas-tugas yang } \\
\text { dibebankan. }\end{array}$ & $\begin{array}{l}\text { a. Suasana kerja } \\
\text { b. Hubungan } \\
\text { dengan rekan } \\
\text { kerja } \\
\text { c. Hubungan } \\
\text { antara } \\
\text { bawahan } \\
\text { dengan } \\
\text { pimpinan } \\
\text { d. Tersedia } \\
\text { fasilitas kerja }\end{array}$ & $\begin{array}{l}\text { Skala } \\
\text { Likert } \\
(1-5)\end{array}$ \\
\hline $\begin{array}{l}\text { KINERJA } \\
\text { PEGAWAI } \\
\text { Ilyas (2012) }\end{array}$ & $\begin{array}{l}\text { Kinerja adalah } \\
\text { penampilan hasil karya } \\
\text { karyawan baik } \\
\text { kuantitas maupun } \\
\text { kualitas dalam suatu } \\
\text { organisasi/perusahaan }\end{array}$ & $\begin{array}{l}\text { a. Prestasi } \\
\text { b. Tanggung } \\
\text { Jawab } \\
\text { c. Ketaatan } \\
\text { d. Kejujuran } \\
\text { e. Kerja Sama } \\
\text { f. Inisiatif } \\
\end{array}$ & $\begin{array}{l}\text { Skala } \\
\text { Likert } \\
(1-5)\end{array}$ \\
\hline
\end{tabular}

\section{Metode Pengumpulan Data}

Metode pengumpulan data yang digunakan dalam penelitian ini adalah data primer dan sekunder. Dalam data primer, peneliti harus melakukan observasi di lapangan secara langsung. Teknik pengumpulan data dapat dilakukan dengan cara kuesioner, skala pengukuran dan dokumentasi. Sedangkan data sekunder diperoleh dari berbagai bahan pustaka seperti jurnal, buku, maupun artikel dari internet yang dapat mendukung dan melengkapi penelitian ini.

\section{Metode Analisis dan Pengujian Hipotesis}

Penelitian ini akan menggunakan alat analisis: 


\section{Uji Validitas dan Realibilitas}

Kualitas data penelitian sangat tergantung pada kualitas data yang dipakai didalam penelitian. Kualitas data penelitian ditentukan oleh instrumen yang digunakan untuk mengumpulkan data untuk menghasilkan data yang berkualitas. Instrumen penelitian yang baik harus memenuhi persyaratan yaitu valid dan reliabel. Uji instrumen penelitian dilakukan melalui uji validitas dan uji reliabilitas untuk memastikan bahwa kuesioner yang disusun dapat dimengerti oleh responden dan memiliki konsistensi pengukuran (Ghozali, 2012).

- Uji Validitas

Uji Validitas digunakan untuk mengetahui tingkat kevalidan dari suatu kuesioner (instrumen) yang digunakan dalam pengumpulan data. Uji validitas dilakukan dengan membandingkan nilai $r$ hitung (Corrected Item-Total Correlation) dengan nilai $r$ tabel. Butir pernyataan dapat dikatakan valid jika $r$ hitung $>r$ tabel atau $r$ hitung $>$ 0,05 .

- Uji Reliabilitas

Uji Reliabilitas adalah alat untuk mengukur suatu kuesioner yang merupakan indikator dari variabel. Suatu kuesioner dikatakan reliabel atau handal jika jawaban seseorang terhadap pernyataan adalah konsisten atau stabil dari waktu ke waktu. Uji reliabilitas dilakukan terhadap keseluruhan butir pernyataan yang telah valid. Uji reliabilitas dilakukan dengan metode Cronbach's Alpha. Reliabilitas terpenuhi jika nilai Cronbach's Alpha > 0,6 (Nunnally dalam Mulyanto dan Wulandari, 2010).

\section{Uji Asumsi Klasik}

Uji Asumsi Klasik yang akan digunakan adalah: Uji Normalitas, Uji Multikolonearitas, dan Uji Heteroskedastisitas.

\section{Analisis Regresi Berganda}

Persamaan analisis regresi berganda (dua prediktor) yang digunakan adalah sebagai berikut: $Y=a+b_{1} X_{1}+b_{2} X_{2}$.
$\mathrm{X}_{1}=$ Disiplin

$\mathrm{X}_{2}=$ Lingkungan Kerja

$\mathrm{Y}=$ Kinerja Pegawai

$\mathrm{a}=$ Konstanta

$\mathrm{b}_{1}=$ Koefisien Disiplin

$b_{2}=$ Koefisien Lingkungan Kerja

\section{Uji Hipotesis}

Uji Hipotesis bertujuan untuk mengetahui apakah pengaruh yang jelas dan dapat dipercaya dari variabel independen terhadap variabel dependen. Maka dapat diambil suatu kesimpulkan untuk menerima atau menolak hipotesis yang diajukan.

- Uji Statistik t

Uji Statistik t untuk mengetahui pengaruh variabel independen secara parsial terhadap variabel dependen. Pengujian ini dilakukan menggunakan tingkat signifikan 0,05 (5\%) (Duwi Priyatno, 2013). Tahaptahap pengujian ini dilakukan sebagai berikut:

a. Menentukan hipotesis nol dan hipotesis alternatif

1) $\mathrm{H}_{0}: \mathrm{b}_{\mathrm{i}}=0$ Artinya tidak ada pengaruh secara parsial antara variabel bebas $(\mathrm{X})$ terhadap variabel terikat $(\mathrm{Y})$.

2) $\mathrm{Ha}:$ bi $\neq 0$

Artinya ada pengaruh secara parsial antara variabel bebas (X) terhadap variabel terikat (Y).

b. Metode pengambilan keputusan

1) Signifikan $\geq 0,05$ jadi $\mathrm{H}_{0}$ diterima

2) Signifikan $\leq 0,05$ jadi $\mathrm{H}_{0}$ ditolak

\section{HASIL DAN PEMBAHASAN \\ Hasil Penelitian \\ Uji Validitas dan Uji Reliabilitas}

Dalam penelitian ini pengujian validitas dilakukan terhadap 67 responden dengan 30 pernyataan. Pengambilan keputusan berdasarkan pada nilai $\mathrm{r}$ hitung (Corrected Item-Total Correlation $)>\mathrm{r}$ tabel sebesar 0,237 $(\mathrm{a}=$ 0,05), maka semua pernyataan dinyatakan valid dan dapat digunakan sebagai indikator dalam penelitian ini. 
Hasil uji reliabilitas menunjukkan bahwa alat ukur yang digunakan 100\% reliabel $(\alpha=0,6)$, yaitu variabel X1 (Disiplin) sebesar 0,946, variabel X2 (Lingkungan Kerja) sebesar 0,933 dan variabel Y (Kinerja Karyawan) sebesar 0,935. Hal ini menunjukkan bahwa semua variable bebas dan variabel terikat dapat dinyatakan reliabel.

\section{Uji Asumsi Klasik}

Hasil uji normalitas dengan $\alpha=5 \%$ diketahui bahwa Disiplin $(0,162)$, Lingkungan Kerja $(0,167)$ dan Kinerja Pegawai $(0,051)$ lebih besar dari 0,05, yang berarti bahwa Ho diterima atau model regresi yang diperoleh berasal dari data variabel yang berdistribusi normal. Dari hasil uji multikolinieritas dapat disimpulkan bahwa di antara variabel bebas tidak ada korelasi. Berdasarkan hasil uji heteroskedastisitas scatterplot dapat diketahui bahwa tidak terjadi heteroskedastisitas.

\section{Uji Model}

\section{Tabel 2}

\begin{tabular}{|c|c|c|c|c|c|c|}
\hline \multicolumn{2}{|c|}{ Model } & \multicolumn{3}{|l|}{ Sum of Squares } & $\mathrm{F}$ & Sig. \\
\hline \multirow{3}{*}{1} & Regression & 4096,585 & 2 & 2048,292 & \multirow[t]{3}{*}{59,971} & \multirow[t]{3}{*}{, $000^{\mathrm{b}}$} \\
\hline & Residual & 2185,893 & 64 & 34,155 & & \\
\hline & Total & 6282,478 & 66 & & & \\
\hline
\end{tabular}

a. Dependent Variable: Kinerja_Karyawan

b. Predictors: (Constant), Lingkungan__Kerja, Disipin

Berdasarkan tabel 2 Anova pada kolom dengan nilai Sig. sebesar 0,000 menunjukan bahwa analisis regresi dalam penelitian ini memiliki model yang dapat diterima karena Sig.< 0.05.

Tabel 3

Model Summaryb

\begin{tabular}{|l|r|r|r|r|r|}
\hline Model & $R$ & R Square & $\begin{array}{c}\text { Adjusted R } \\
\text { Square }\end{array}$ & $\begin{array}{c}\text { Std. Error of } \\
\text { the Estimate }\end{array}$ & $\begin{array}{c}\text { Durbin- } \\
\text { Watson }\end{array}$ \\
\hline 1 &, $808 \mathrm{a}$ &, 652 &, 641 & 5,844 & 1,728 \\
\hline & & & & & \\
\hline
\end{tabular}
a. Predictors: (Constant), Linekunean_Keria, Disipin
b. Dependent Variable: Kinerja_Pegawai

Dari tabel di atas menghasilkan nilai $R$ Square sebesar 0,652, hal ini menunjukkan bahwa variabel disiplin (X1) dan lingkungan kerja (X2) menjelaskan perubahan pada variabel kinerja pegawai (Y) sebesar $65,2 \%$ sedangkan sisanya yaitu $34,8 \%$ dijelaskan oleh faktor-faktor lain di luar model.

\section{Analisis Regresi Berganda}

Analisis regresi berganda digunakan untuk mengetahui pengaruh variabel bebas terhadap variabel terikat, dengan persamaan regresi adalah $Y=a+$ $b 1 X 1+b 2 X 2$. Hasil perhitungan regresi berganda dapat dilihat pada tabel berikut ini:

Tabel 4

Coefficients:

\begin{tabular}{|c|c|c|c|c|c|c|c|}
\hline \multirow[t]{2}{*}{ Model } & \multicolumn{2}{|c|}{$\begin{array}{l}\text { Unstandardized } \\
\text { Coefficients }\end{array}$} & \multirow{2}{*}{$\begin{array}{c}\begin{array}{c}\text { Standardized } \\
\text { Coefficients }\end{array} \\
\text { Beta } \\
\end{array}$} & \multirow[t]{2}{*}{$\mathrm{t}$} & \multirow[t]{2}{*}{ Sig. } & \multicolumn{2}{|c|}{$\begin{array}{c}\text { Collinearity } \\
\text { Statistics }\end{array}$} \\
\hline & B & Std. Error & & & & Tolerance & VIF \\
\hline \multirow[b]{3}{*}{$\begin{array}{l}\text { Linghungan_ } \\
\text { Keris }\end{array}$} & 9.195 & 2.767 & & 3.322 & .001 & & \\
\hline & .290 &, 110 & ,303 & 2,634 & 011 & ,411 & 2,430 \\
\hline &, 527 &, 110 &, 552 & 4,798 &, 000 & ,411 & 2,430 \\
\hline
\end{tabular}

a. Dependent Variable: Kinerja_Pegawai

Dari persamaan regresi tersebut dapat diinterprestasikan sebagai berikut:

$$
\mathrm{Y}=9,195+0,290 \mathrm{X} 1+0,527 \mathrm{X} 2
$$

Dari hasil analisa di atas dapat disimpulkan sebagai berikut:

1. Pada persamaan regresi diatas menunjukkan nilai konstanta sebesar 9,195, hal ini menyatakan bahwa jika variabel disiplin dan lingkungan kerja dianggap konstan atau bernilai 0 (nol), maka kinerja karyawan akan meningkat sebesar 9,195 satuan.

2. Koefisien regresi pada variabel disiplin (X1) 0,290, hal ini berarti jika variabel disiplin bertambah satu satuan maka variabel kinerja karyawan akan meningkat sebesar 0,290 satuan.

3. Koefisien regresi pada variabel lingkungan kerja (X2) sebesar 0,527, hal ini berarti jika variabel lingkungan kerja bertambah satu satuan maka variabel kinerja karyawan akan meningkat sebesar 0,527 satuan.

Dari hasil koefisien regresi terlihat bahwa lingkungan kerja (X2) mempunyai pengaruh lebih tinggi dibandingkan disiplin (X1) terhadap kinerja karyawan (Y) pada Asisten Deputi SDM Pariwisata dan Hubungan Antar Lembaga Kementerian Pariwisata RI, yang didasarkan pada nilai koefisien 
regresi sebesar 0,527 (unstadardized coeficients) dan nilai beta sebesar 0,552 (standardized coefficients) dengan signifikan sebesar 0,000 atau sig. sebesar $0 \%$.

\section{Uji t (Uji Hipotesis secara Parsial)}

Digunakan untuk mengetahui pengaruh masing-masing variabel bebas (disiplin dan lingkungan kerja) terhadap variabel terikat (kinerja karyawan). Pengujian hipotesis ditunjukkan dalam tabel berikut ini:

Tabel 5

Coefficients:

\begin{tabular}{|l|r|r|r|r|r|}
\hline \multirow{2}{*}{ Model } & \multicolumn{2}{|c|}{$\begin{array}{c}\text { Unstandardized } \\
\text { Coefficients }\end{array}$} & $\begin{array}{c}\text { Standardized } \\
\text { Coefficients }\end{array}$ & \multirow{2}{*}{$\mathrm{t}$} & \multirow{2}{*}{ Sig. } \\
\cline { 2 - 4 } & \multicolumn{1}{|c|}{$\mathrm{B}$} & Std. Error & \multicolumn{1}{c|}{ Beta } & & \\
\hline \multirow{2}{*}{$\begin{array}{l}\text { (Constant) } \\
1\end{array}$ Disivin } & 9,195 & 2,767 & & 3,322 &, 001 \\
Lingkungan & .290 & .110 & .303 & 2.634 & .011 \\
Keria &, 527 &, 110 &, 552 & 4,798 &, 000 \\
\hline
\end{tabular}

a. Dependent Variable: Kinerja_Pegawai

Berdasarkan tabel di atas, maka dapat disimpulkan persamaan regresi linear yaitu: $\mathrm{Y}=9,195+0,290 \mathrm{X} 1+$ 0,527X2 dan didapatkan pengujian hipotesis sebagi berikut:

1) Pengaruh Disiplin terhadap Kinerja Pegawai

Berdasarkan hasil uji statistik, diperoleh t hitung sebesar 2,634 dan nilai signifikan sebesar 0,011 . Nilai $t$ hitung sebesar 2,634 lebih besar dari nilai $\mathrm{t}$ tabel $1,668(2,634>1,668)$ atau sama dengan nilai signifikan 0,011 kurang dari 0,05 $(0,011<$ $0,05)$ maka Ho ditolak dan $\mathrm{Ha}$ diterima. Jadi, dapat disimpulkan bahwa disiplin berpengaruh signifikan terhadap kinerja karyawan.

2) Pengaruh Lingkungan Kerja terhadap Kinerja Pegawai

Berdasarkan hasil uji statistik, diperoleh t hitung sebesar 4,798 dan nilai signifikan sebesar 0,000 . Nilai t hitung sebesar 4,798 lebih besar dari nilai $t$ tabel $1,668(4,798>1,668)$ atau sama dengan nilai signifikan 0,000 kurang dari 0,05 $(0,000<$ $0,05)$ maka Ho ditolak dan $\mathrm{Ha}$ diterima. Jadi, dapat disimpulkan bahwa lingkungan kerja berpengaruh signifikan terhadap kinerja pegawai.

\section{Pembahasan}

Pengukuran variabel penelitian dilakukan dengan menggunakan kuesioner yang dikembangkan dari indikator pada masing-masing variabel penelitian. Dari hasil uji validitas terhadap masing-masing variabel penelitian ditemukan bahwa seluruh item pernyataan pada setiap variabel telah valid. Melalui uji reliabilitas ditemukan bahwa seluruh butir pernyataan yang telah valid pada masing-masing variabel penelitian dapat dibuktikan reliabilitasnya. Karena kuesioner telah valid dan reliabel maka kuesioner penelitian merupakan alat yang handal untuk mengukur masingmasing variabel penelitian.

Analisis deskriptif terhadap variabel penelitian menghasilkan temuan yang relatif sama untuk semua variabel penelitian dimana persepsi responden terhadap disiplin dan lingkungan kerja baik.

Gambar 3

Rangkuman Hasil Analisis $\operatorname{Sig} \mathrm{F}=0,000<(\alpha=0,05)$

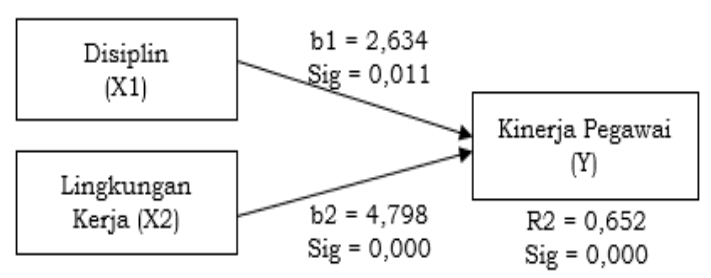

Penelitian menghasilkan model yang layak dimana model hasil penelitian mampu menjelaskan $65,2 \%$ variasi kinerja pegawai karena masukan faktor disiplin dan lingkungan kerja.

\section{Pengaruh Disiplin terhadap Kinerja Pegawai}

Hasil dari penelitian ini menyebutkan bahwa disiplin memiliki pengaruh signifikan terhadap kinerja pegawai. Hal tersebut dibuktikan dari hasil perhitungan koefisien regresi X1 sebesar $b 1=0,290$ dan memiliki nilai probabilitas $t$ hitung lebih kecil daripada taraf uji penelitian ( $\operatorname{sig} \mathrm{t}<\mathrm{a}$ atau 0,011 < 0,05). Hasil penelitian ini juga sejalan dengan penelitian yang dilakukan oleh Rizon Pranata (2014), Muhammad 
Taufiek Rio Sanjaya (2015) dan Tri Widari (2016), yang dalam penelitiannya menyatakan bahwa disiplin memiliki pengaruh signifikan terhadap kinerja karyawan.

Ketika tingkat disiplin suatu perusahaan itu tinggi maka diharapkan pegawai akan bekerja lebih baik, sehingga kinerja pegawai terus meningkat. Selain itu disiplin kerja yang baik akan meningkatkan efisiensi kerja semaksimal mungkin, tidak menghabiskan waktu yang banyak bagi organisasi untuk sekedar melakukan pembenahan diaspek kedisplinan tersebut dan waktu dapat digunakan untuk mencapai tujuan perusahaan. Seperti yang dikatakan Setiyawan dan Waridin (2006:189) bahwa disiplin adalah suatu bentuk ketaatan terhadap aturan, baik tertulis maupun tidak tertulis yang telah ditetapkan. Disiplin kerja pada dasarnya selalu diharapkan menjadi ciri setiap sumber daya manusia dalam organisasi, karena dengan kedisplinan organisasi akan berjalan dengan baik dan bisa mencapai tujuannya dengan baik pula.

\section{Pengaruh Lingkungan Kerja terhadap Kinerja Pegawai}

Hasil dari penelitian ini menyebutkan bahwa lingkungan kerja memiliki pengaruh signifikan terhadap kinerja pegawai. Hal tersebut dibuktikan dari hasil perhitungan koefisien regresi $\mathrm{X} 2$ sebesar b2 = 0, 527 dan memiliki nilai probabilitas $\mathrm{t}$ hitung lebih kecil daripada taraf uji penelitian $(\operatorname{sig} \mathrm{t}<\mathrm{a}$ atau $0,000<0,05)$. Hasil penelitian ini juga sejalan dengan penelitian yang dilakukan oleh Dilian Diah Pertiwi (2014) dan Aditya Nur Pratama (2016), yang dalam penelitiannya menyatakan bahwa lingkungan kerja memiliki pengaruh signifikan terhadap kinerja karyawan.

Kondisi lingkungan kerja yang baik akan membuat pegawai merasa nyaman dalam bekerja. Kenyamanan tersebut tentunya akan berdampak pada peningkatan kinerja pegawai. Sebaliknya, ketidaknyamanan dari lingkungan kerja yang dialami oleh pegawai bisa berakibat fatal yaitu menurunnya kinerja pegawai itu sendiri. Kondisi yang hendaknya diciptakan adalah suasana kekeluargaan, komunikasi yang baik dan pengendalian diri. Lingkungan kerja dapat diartikan sebagai kekuatan-kekuatan yang mempengaruhi, baik secara langsung maupun tidak langsung terhadap kinerja organisasi atau perusahaan (Terry, 2006).

\section{KESIMPULAN \\ Simpulan}

Berdasarkan pada data yang telah dikumpulkan dan pengujian yang telah dilakukan terhadap permasalahan, maka dapat diambil kesimpulan sebagai berikut:

1. Disiplin berpengaruh signifikan terhadap kinerja pegawai. Hasil penelitian yang menunjukkan bahwa variabel disiplin memiliki nilai $\beta$ sebesar 0,290 dengan tingkat signifikan sebesar $(0,011)<a(0,05)$. Artinya semakin meningkat kedisiplinan pegawai, maka akan meningkatkan kinerja pegawai.

2. Lingkungan kerja berpengaruh signifikan terhadap kinerja pegawai. Hasil penelitian yang menunjukkan bahwa variabel lingkungan kerja memiliki nilai $\beta$ sebesar 0,527 dengan tingkat signifikan sebesar $(0,000)<a(0,05)$. Artinya semakin baik kondisi/keadaan dan suasana lingkungan kerja yang nyaman maka akan meningkatkan kinerja pegawai.

\section{Saran}

Penelitian ini di masa mendatang diharapkan dapat menyajikan hasil penelitian yang lebih berkualitas lagi dengan adanya beberapa masukan mengenai beberapa hal diantaranya:

1. Terkait dengan disiplin pimpinan dan seluruh pegawai pada Asisten Deputi SDM Pariwisata dan Hubungan Antar Lembaga Kementerian Pariwisata RI disarankan untuk menjaga peraturan yang sudah ada, mempertahankan dan melaksanakannya untuk semua pihak di perusahaan tanpa 
terkecuali, serta dikelola dalam pengawasan sebuah manajemen personalia, agar tidak terjadi kelengahan, sehingga kinerja karyawan dapat meningkat. Selain itu, perlu dilakukan pengawasan terhadap kedisiplinan pegawai seperti absensi pegawai dilakukan secara modern dengan menggunakan alat bantu seperti finger print untuk menjamin kejujuran dalam penilaiannya.

2. Terkait dengan lingkungan kerja pada Asisten Deputi SDM Pariwisata dan Hubungan Antar Lembaga Kementerian Pariwisata RI disarankan untuk selalu menjaga dan mempertahankan hubungan dan komunikasi yang baik terhadap pimpinan dan seluruh pegawai tanpa terkecuali. Selain itu juga disarankan agar dilakukan evaluasi mingguan atau bulanan terkait permasalahan yang terjadi di antara sesama pegawai agar hubungan yang baik selalu terjaga. Hal lain yang perlu dipertimbangkan adalah pengadaan refreshing bersama sebagai sarana mempererat tali silaturahmi antar sesama para pegawai dan pimpinan sehingga pegawai merasa nyaman baik di dalam atau di luar kerja. Apabila hubungan antar pegawai terlihat harmonis dan baik, maka pegawai akan cenderung nyaman dalam bekerja sehingga berdampak pada meningkatnya kinerja pegawai.

\section{DAFTAR PUSTAKA}

Arep, Ishak dan Hendri Tanjung. (2003). Manajemen Sumber daya Manusia. Universitas Trisakti: Jakarta.

Ghozali, Imam. (2012). Aplikasi Analisis Multivariate dengan SPSS. Semarang: Badan Penerbit Universitas Diponegoro.

Hasibuan, Malayu. (2005). Manajemen Sumber Daya Manusia. Edisi Revisi. Jakarta: PT. Bumi Aksara.

Hasibuan, Malayu. (2012). Manajemen Sumber Daya Manusia. Cetakan XVI. Jakarta: PT. Bumi Aksara.
Ilyas, Yaslis. (2012). Kinerja, Teori, Penilaian dan Penelitian. Jakarta: Pusat Kajian Ekonomi Kesehatan FKM Universitas Indonesia.

Irmin, Soejitno dan Abdul Rochim. (2004). Membangun Disiplin Diri Melalui Kecerdasan Spiritual dan Emosional. Yogyakarta: Batavia Pers.

Mahsun, Mohamad. (2006). Pengukuran Kinerja Sektor Publik. Cetakan Pertama. Yogyakarta: Penerbit BPFE-Yogyakarta.

Mangkunegara, A.A. Anwar Prabu. (2004). Manajemen Sumber Daya Manusia Perusahaan. Bandung: Remaja Rosda Karya.

Mangkunegara, A.A. Anwar Prabu. (2011). Manajemen Sumber Daya Manusia Perusahaan. Bandung: Remaja Rosdakarya.

Mathis Robert, Jackson John. (2002). Manajemen Sumber Daya Manusia. Jakarta: Salemba Empat.

Mulyanto, Heru dan Anna Wulandari. (2010). Penelitian: Metode dan Analisis, CV. Agung, Semarang.

Nitisemito, A.S. (2010). Manajemen Personalia dan Manajemen Sumber

Daya Manusia. Jakarta: Ghalia Indonesia.

Pertiwi, Diah, Dilian. (2014). Pengaruh Kompensasi, Motivasi dan Lingkungan Kerja terhadap Kinerja Karyawan Dinas Pendapatan Pengolaan Keuangan dan Aset Daerah Kabupaten Klaten. Surakarta: Fakultas Ekonomi dan Bisnis, Universitas Muhammadiyah Surakarta.

Pranata, Rizon. (2014). Pengaruh Motivasi dan Disiplin terhadap Kinerja Karyawan PT. Adira Dinamika Multi Finance Tbk. Arga Makmur Bengkulu Utara. Bengkulu: Fakultas Ekonomi dan Bisnis, Universitas Bengkulu.

Pratama, Nur, Aditya. (2016). Pengaruh Lingkungan Kerja dan Disiplin terhadap Kinerja Karyawan PT. Razer Brothers. Yogyakarta: Fakultas Ekonomi, Universitas Negeri Yogyakarta. 
Priyatno, Duwi. (2013). Analisis Korelasi, Regresi dan Multivariate dengan SPSS. Yogyakarta: Gava Media.

Rivai, Veithzal dan Sagala, Ella Jauvani. (2010). Manajemen Sumber Daya Manusia untuk Perusahaan dari Teori ke Praktik. Jakarta: PT. Raja Grafindo.

Rivai, Veithzal Fauzi dan Basri, MA. (2005). Perfomance Appraisal. Jakarta: PT. Raja Grafindo Persada.

Rivai, Veithzal. (2009). Manajemen Sumber Daya Manusia untuk Perusahaan dari Teori ke Praktik. Jakarta: Raja Grafindo Persada.

Sanjaya, Rio, Taufiek, M. (2015). Pengaruh Disiplin dan Motivasi terhadap Kinerja Karyawan pada Hotel Ros In Yogyakarta. Yogyakarta: Fakultas Ekonomi, Universitas Yogyakarta.

Schultz, G.S., Sibbald, R.G., Falanga, V., Ayello, E.A., Dowsett, C., Harding, K., \& Vanscheidt, W. (2006). Wound Bed Preparation: A Systematic Approach to Wound Management. Wound repair and regeneration, 11(s1), S1-S28.

Sedarmayanti. (2001). Sumber Daya Manusia dan Produktivitas Kerja. Jakarta: Mandar Maju.

Sedarmayanti. 2017. Tata Kerja dan Produktivitas Kerja. Mandar Maju. Bandung.

Setiyawan, Purnomo Budhi dan Waridin. (2006). Pengaruh Disiplin Kerja Karyawan dan Budaya Organisasi terhadap Kinerja di Divisi Radiologi RSUP Dokter Kariadi Semarang. Jurnal Riset Bisnis Indonesia. Vol. 2. No. 2. Juli. Hal. 181 -198. Unissula. Semarang.

Siagian, S. P. (2012). Kiat Meningkatkan Produktivitas Kerja. Jakarta: PT. Rineka Cipta.

Simanjuntak. (2005). Manajemen dan Evaluasi Kinerja. Jakarta: Fakultas Ekonomi Universitas Indonesia.

Singarimbun, Masri \& Effendi Sofian. (2009). Metode Penelitian Survai. Jakarta: LP3ES.

Terry, George R. (2006). Prinsip-prinsip Manajemen. Jakarta: Bumi Aksara.

Widari, Tri. (2016). Pengaruh Disiplin dan Lingkungan Kerja terhadap
Kinerja Karyawan Badan Kepegawaian Daerah Istimewa Yogyakarta. Yogyakarta: Fakultas Ekonomi, Universitas Negeri Yogyakarta. 